\title{
IMPLEMENTASI DATA MINING METODE ASOSIASI ALGORITMA FP-GROWTH PADA PERUSAHAAN RITEL
}

\author{
Alexander Radityo Wibowo ${ }^{1}$, Arief Jananto ${ }^{2}$ \\ Program Studi Sistem Informasi, Fakultas Teknologi Informasi, Universitas Stikubank ${ }^{1,2}$ \\ Email : wiboworadityo1@email.com¹, ajananto09@edu.unisbank.ac.id ${ }^{2}$
}

\begin{abstract}
ABSTRAK
Toko Gunung Agung Cabang Semarang adalah salah satu perusahaan ritel yang berada di Kota Semarang, menjual buku-buku, peralatan kantor dan sekolah. Setiap transaksi penjualannya selalu dicatat dan didokumentasikan. Pendokumentasian dan catatan-catatan itu membentuk data dan tersimpan di basis data. Data-data yang tersimpan tersebut akan terus bertambah. Sehingga jumlah data yang tersimpan dalam basis data dan semakin besar ini akan dimanfaatkan dengan menggunakan ilmu data mining. Metodologi yang digunakan untuk pemecahan masalah dalam penelitian ini adalah CRISP-DM (CRoss-Industry Standard Process for Data Mining). Dan menggunakan teknik data mining association. Dari penerapan teknik asosiasi tersebut akan menghasilkan aturan asosiasi atau hubungan antar produk. Dari pengetahuan berupa rule asosiasi yang ditemukan, selanjutnya dimanfaatkan untuk menentukan tata letak barang dagangan sebagai salah satu strategi penjualan. Dari hasil penelitian, perhitungan menggunakan algoritma FP-Growth dengan parameter minimum support 0.04 dan confidence 0.2 secara manual dan menggunakan tools Rstudio untuk 100 transaksi pertama telah menghasilkan rule asosiasi yang sama. Selanjutnya, untuk seluruh transaksi penjualan periode 1 tahun (1 September 2019 sampai 31 Agustus 2020) yaitu sebanyak 57.449 transaksi dengan 133.571 record dengan menggunakan Rstudio telah menghasilkan 6 rule. Sehingga untuk mengatur tata letak barang berdasarkan rule hasil perhitungan semua data tersebut, barang dengan kode kategori H (WRITING INSTRUMENT) harus diletakkan berdekatan dengan barang berkategori G (SCHOOL STATIONERY) dan kategori F (OFFICE ESSENTIAL).
\end{abstract}

Kata Kunci: Data Mining, Asosiasi, FP-Growth

\begin{abstract}
TokoGunung Agung Semarang Branch is a retail company located in the city of Semarang, selling books, office equipment, and school stationary. Every sales are always recorded and documented. The documentation and records form data and stored in a database. The stored data will continue to grow. So that the greater the amount of data stored in the database will be utilized by using data mining science. The methodology used for the problems in this study is CRISP-DM (CRoss-Industry Standard Process for Data Mining). And using data mining association techniques. The application of the association technique will produce association rules or relationships between products. From the knowledge which is found in the form of association rules, it is then used to determine the products layout as a sales strategy. From the research results, the calculation using the FP-Growth algorithm with a parameter of minimum support 0.04 and confidence 0.2 manually and using the Rstudio tool for the first 100 transactions has resulted in the same association rule. Furthermore, for all sales transactions for the period of 1 year (September 1, 2019 to August 31, 2020), as many as 57,449 transactions
\end{abstract}


with 133,571 records using Rstudiotool have produced 6 rules. So that in order to arrange the layout of goods based on the calculation result rule of all the data, items with category $H$ (WRITING INSTRUMENT) must be placed close to items with category code G (SCHOOL STATIONERY) and goods with category F (OFFICE ESSENTIAL).

Keywords: Data Mining, Association, FP-Growth

\section{PENDAHULUAN}

Salah satu faktor penting untuk menentukan strategi bisnis adalah pengambilan keputusan dengan cepat dan akurat. Dalam pengambilan keputusan para eksekutif tidak dapat lagi menggunakan intuisi, namun perlu dilakukan berdasarkan data. Bicara tentang data bagi sebuah perusahaan, setiap transaksi kegiatan operasinya selalu dicatat dan didokumentasikan. Pendokumentasian dan catatan-catatan itu membentuk data dan tersimpan di basis data. Data-data tersebut akan tersimpan dan akan terus bertambah.

Misalnya dalam sebuah perusahaan ritel atau toko, dalam satu hari ada berapa banyak transaksi penjualan, dalam seminggu, dalam sebulan, dalam setahun ada berapa juta data transaksi yang tersimpan di database perusahaan tersebut. Kenyataan bahwa jumlah data yang tersimpan dalam basis data semakin besar ini telah menjadi dasar munculnya Data Mining.

Data Mining dapat diartikan sebagai pengekstrakan informasi baru yang diambil dari data yang besar yang membantu dalam pengambilan keputusan (Prasetyo, 2012). Istilah Data Mining kadang juga disebut knowledge discovery. Di dalam Data Mining ada berbagai macam teknik, salah satunya adalah teknik asosiasi. Teknik asosiasi tersebut akan digunakan untuk menentukan aturan asosiasi atau hubungan antar produk. Hubungan antar produk yang dihasilkan akan dimanfaatkan untuk menentukan tata letak barang dagangan sebagai salah satu strategi penjualan.
Perancangan products layout atau tata letak barang merupakan sebuah kegiatan rutin di Toko Gunung Agung Cabang Semarang. Akan tetapi terdapat permasalahan yaitu perbedaan pendapat dalam menentukan tata letak tersebut. Misalnya eksekutif (manajer) memiliki pendapat berbeda dengan supervisor, supervisor berbeda pendapat dengan pramuniaga yang di lapangan, dan sebaliknya. Selama ini pengaturan tata letak barang di toko tersebut berdasarkan pada pengalaman atau insting semata sehingga setiap orang memiliki pendapat yang berbeda-beda. Berangkat dari uraian tersebut, dengan teknik asosiasi Data Mining peneliti akan mencari pola asosiasi barang terjual untuk menentukan products layout atau tata letak barang di perusahaan ritel tersebut berdasarkan pada data transaksi penjualan.

\section{LANDASAN TEORI}

2.1. Pustaka yang Terkait Dengan Penelitian Sebelumnya

Bicara tentang data dalam data mining, tidak ada batasan berapa banyak data yang digunakan dalam implementasinya. Bisa saja menggunakan data transaksi penjualan selama satu bulan untuk menentukan hubungan antar barang dengan menggunakan teknik Data Mining (Marsono, 2019).

Penelitian ini secara konsep sama dengan penelitian Robi Yanto dan Hendra Di Kesuma, di mana mereka mencari pola penempatan buku berdasarkan data kunjungan perpustakaan (Yanto \& Kesuma, 2017). Sedangkan yang penulis lakukan pada 
penelitian ini yaitu mecari pola pembeli sebagai dasar menentukan tata letak barang dari data penjualan. Akan tetapi algoritma untuk pemecahan masalah yang penulis pilih ialah algoritma FP-Growth.

Algoritma FP-Growth telah menemukan aturan asosiasi lebih banyak dan proses lebih cepat dibandingkan Apriori (Salam et al., 2019). Selain itu, tingkat akurasi algoritma FP-Growth juga lebih besar dibandingkan apriori (Maulidiya \& Jananto, 2020).

\subsection{Pengertian Data Mining}

Data mining dapat diartikan sebagai kegiatan melakukan ekstraksi untuk mendapatkan informasi penting yang sifatnya implisit dan sebelumnya tidak diketahui, dari suatu data (Witten, 2017). Data mining merupakan kegiatan yang meliputi pengumpulan, pemakaian data historis untuk menemukan keteraturan, pola dan hubungan dalam set data berukuran besar (Susanto, 2007). Dari definisi-definisi tersebut, maka dapat diartikan bahwa data mining adalah disiplin ilmu yang mempelajari metode untuk mengekstrak pengetahuan atau menemukan pola atau hubungan dari suatu data yang besar.

\subsection{CRISP-DM}

CRoss-Industry Standard Process for Data Mining atau sering disebut dengan CRISP-DM merupakan salah satu metode standar proses data mining sebagai strategi pemecahan masalah secara umum dari bisnis atau unit penelitian. Metode ini sudah dikembangkan sejak tahun 1996 oleh analis dari beberapa industry seperti Daimler-Benz (sekarang Daimler Chrysler), Integral Solutions Ltd. (ISL), NCR, dan OHRA. Berikut ini adalah tahap-tahap metodologi CRISP-DM:

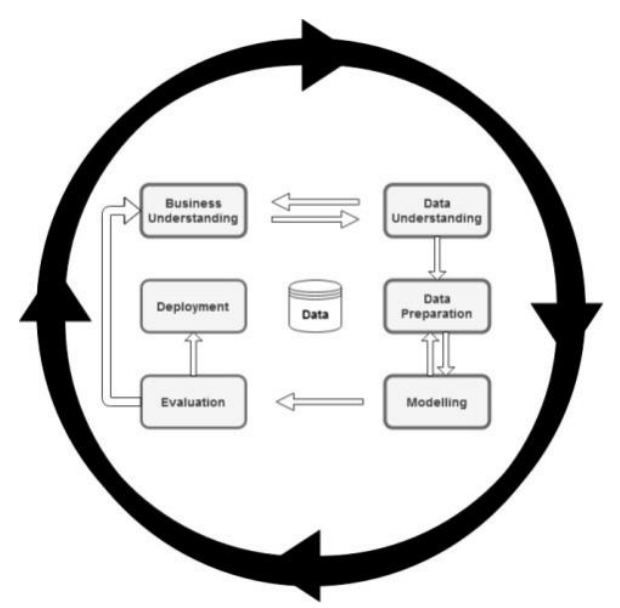

Gambar 1. Metode CRISP-DM

\section{Business Understanding}

Tahap ini merupakan tahap terpenting dari setiap proyek data mining yaitu pemahaman kegiatan data mining dari perspektif bisnis. Kegiatan yang dimaksud di sini ialah menentukan sasaran atau tujuan bisnis, memahami situasi bisnis, menentukan tujuan data mining dan membuat perencanaan penelitian.

2. Data Understanding

Tahap pemahaman data dimulai dengan pengumpulan data awal. Kemudian mempelajari dan memahami data, mengidentifikasi kualitas data, dan mendeteksi subset untuk menentukan hipotesa awal.

\section{Data Preparation}

Tahap persiapan data meliputi seluruh kegiatan pembuatan dataset yang akan diproses pada tahap berikutnya (modeling). Kegiatan yang dilakukan pada tahap ini yaitu memilih table, field, record, data cleaning, dan transformasi data sesuai dengan tools yang digunakan pada tahap modeling.

4. Modeling

Kegiatan yang dilakukan pada tahap ini adalah menentukan teknik data 
mining yang digunakan, menentukan tools data mining, teknik data mining, algoritma data mining, dan menentukan parameter dengan nilai yang optimal. Beberapa teknik data mining membutuhkan persyaratan khusus sehingga bisa saja kembali ketahap sebelumnya (Data Preparation) untuk memenuhi syarat tersebut.

\section{Evaluation}

Tahap ini merupakan tahap untuk mengevaluasi dan memastikan bahwa model yang dibuat sesuai dengan tujuan awal. Apabila sudah benar, maka dilanjutkan ketahap berikutnya yaitu tahap Deployment. Sebaliknya, apabila tidak sesuai dengan tujuan atau sasaran awal maka kembali lagi ke tahap pertama (Business Understanding) supaya hasil dari data mining sesuai dengan tujuan awal.

6. Deployment

Pada tahap ini, pengetahuan yang diperoleh dari proses data mining dapat disajikan sedemikian rupa supaya dapat digunakan untuk mengambil keputusan. Misalnya disajikan dalam bentuk presentasi atau laporan.

\subsection{Asosiasi Data Mining}

Analisis asosiasi atau association data mining merupakan salah satu metode dalam data mining untuk menemukan aturan asosiatif pada kombinasi item atau hubungan antar atribut. Analisis keranjang belanja atau association rule mining adalah salah satu metode data mining yang berfokus untuk menemukan pola pembelian dengan mengekstrak asosiasi atau data transaksi di sebuah toko (Prahartiwi, 2017). Analisis aturan asosiasi berguna untuk menemukan hubungan antar item dalam suatu data yang besar. Hubungan antar item yang ditemukan akan dipresentasikan dalam bentuk aturan asosiasi atau association rule atau set aturan yang sering muncul.

Analisis asosiasi terbagi menjadi dua tahap. Pertama, analisa pola frekuensi tinggi yaitu mencari kombinasi item yang memenuhi syarat minimum dari nilai support. Rumus untuk menghitung nilai support adalah sebagai berikut:

$$
\begin{aligned}
& \text { Support }(A) \\
& =\frac{\text { Jumlah Transaksi Mengandung A }}{\text { Total Transaksi }} \times 100 \%
\end{aligned}
$$

$\operatorname{Support}(A, B)=$

$\frac{\text { Jumlah Transaksi Mengandung A dan B }}{\text { Total Transaks }} \times 100 \%$

Kedua, pembentukan aturan asosiasi yaitu mencari item yang memenuhi syarat minimal confidence dengan menghitung confidence aturan asosiasi.

$$
\begin{aligned}
& \text { Confidence }(A \rightarrow B)= \\
& P(A \mid B) \\
& =\frac{\text { Jumlah Transaksi Mengandung A dan } B}{\text { Jumlah Transaksi Mengandung } A} \times 100 \%
\end{aligned}
$$

\subsection{Algoritma Frequent Pattern Growth (FP-Growth) \\ FP-Growth merupakan salah satu algoritma dari data mining asosiasi. Algoritma FP-Growth digunakan untuk menemukan himpunan data yang sering muncul (frequent itemset) dari kumpulan data. Ada tiga tahapan utama dalam}


algoritma FP-Growth yaitu tahap pembangkitan conditional pattern base, tahap pembangkitan conditional FP-Tree, dan tahap pencarian frequent itemset. Namun sebelum ketahapan utama tersebut, ada beberapa tahap yang harus dilakukan terlebih dahulu antara lain:

Penyiapan dataset

1. Pencarian frequent itemset

2. Mengurutkan berdasarkan priority

3. Dataset (item dalam setiap transaksi) diurutkan berdasarkan priority

4. Membentuk FP-Tree

Setelah FP-Tree terbentuk, barulah melakukan tiga tahapan utama dalam algoritma $\mathrm{FP}$-Growth

1. Tahap Pembangkitan Conditional Pattern Base

Conditional pattern base merupakan hasil dari lintasan FP-Tree yang terbentuk dengan mempertimbangkan item dengan support count terkecil atau anak root terakhir.

2. Tahap Pembangkitan Conditional FPTree

Pertama yang dilakukan pada tahap ini ialah menentukan minimum support. Selanjutnya, menjumlahkan support count setiap item pada conditional pattern base. Hasil penjumlahan yang memenuhi minimum support akan dibangkitkan kembali dengan conditional FP-Tree.

3. Tahap Pembangkitan Frequent Itemset Frequent Itemset dibentuk berdasarkan kombinasi setiap item dalamFP-Tree berupa rule. Apabila dalam FP-Tree terdapat item yang sama pilih support count dengan nilai terkecil.

\section{METODE PENELITIAN}

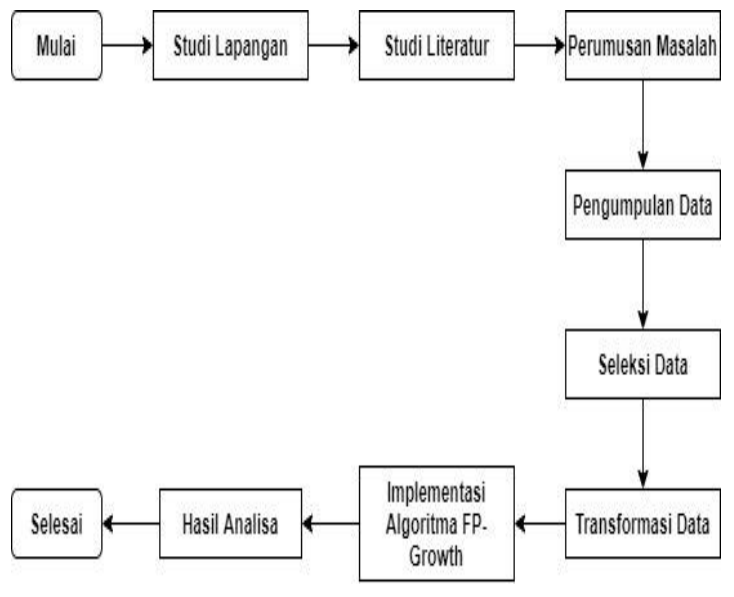

Gambar 2. Flowchart tahap penelitian

Tahap pertama dalam penelitian ini adalah studi lapangan, yang dilakukan dalam tahap ini yaitu melakukan observasi di Toko Gunung Agung Cabang Semarang.

Tahap berikutnya ialah studi literatur. Pada tahap ini peneliti mengumpulkan semua informasi yang dibutuhkan. Informasiinformasi tersebut didapat dari buku, jurnal, artikel, dan lain-lain.

Tahap selanjutnya ialah merumuskan masalah dari permasalahan yang didapatkan pada saat observasi di lapangan yaitu bagaimana mengatur tempat display atau tata letak barang dagangan di Toko Gunung Agung Cabang Semarang berdasarkan data transaksi penjualan.

Setelah perumusan masalah, tahap selanjutnya ialah mengumpulkan data yang dibutuhkan dalam penelitian ini. Data yang digunakan dalam penelitian ini adalah data transaksi penjualan Toko Gunung Agung Cabang Semarang periode 1 tahun (1 September 2019 sampai 31 Agustus 2020). Data berasal dari database Microsoft SQL Server 2000, kemudian dilakukan export data ke excel. Data tersebut memiliki 69.677 transaksi dengan 205.687 record. Potongan 
data transaksi asli untuk 24 record teratas sebelum diolah dapat dilihat pada Gambar 3.

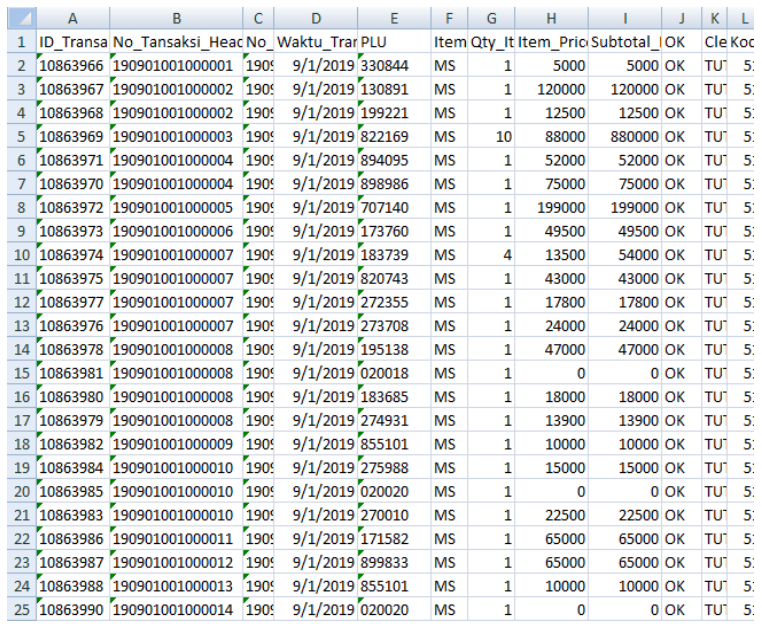

Gambar 3. Potongan data transaksi penjualan

Penjelasan tiap kolom/field pada potongan data transaksi penjualan di atas dapat dilihat pada Tabel 1.

Tabel 1. Keterangan field data transaksi penjualan

\begin{tabular}{|c|l|l|}
\hline No & Nama Kolom/Field & \multicolumn{1}{|c|}{ Keterangan } \\
\hline 1. & ID_Transaksi & $\begin{array}{l}\text { Nomor urut } \\
\text { transaksi }\end{array}$ \\
\hline 2. & No_Tansaksi_Header & $\begin{array}{l}\text { Nomor transaksi } \\
\text { (nota) }\end{array}$ \\
\hline 3. & No_Transaksi_Detail & $\begin{array}{l}\text { Nomor detail } \\
\text { transaksi }\end{array}$ \\
\hline 4. & Waktu_Transaksi & Waktu transaksi \\
\hline 5. & PLU & Kode barang \\
\hline 6. & Item_Owner & $\begin{array}{l}\text { Keterangan } \\
\text { kepemilikan barang }\end{array}$ \\
\hline 7. & Qty_Item & $\begin{array}{l}\text { Kuantiti } \\
\text { transaksi }\end{array}$ \\
\hline 8. & Item_Price & Harga per barang \\
\hline 9. & Subtotal_Price & $\begin{array}{l}\text { Total harga barang } \\
\text { kali kuantiti item }\end{array}$ \\
\hline 10. & OK & $\begin{array}{l}\text { Keterangan } \\
\text { transaksi }\end{array}$ \\
\hline 11. & Clerk_ID & Nama kasir \\
\hline
\end{tabular}

\begin{tabular}{|l|l|l|}
12. & Kode_Cabang & Kode cabang \\
\hline 13. & IsDiscount & Diskon barang total \\
\hline 14. & Deskripsi & Nama barang \\
\hline 15. & No_Bon & Nomor nota \\
\hline 16. & NoMesin & Nomor mesin kasir \\
\hline 17. & Diskon & Diskon barang \\
\hline 18. & Kode_Kategori & $\begin{array}{l}\text { Kode kategori } \\
\text { barang }\end{array}$ \\
\hline 19. & Nama_Kategori & $\begin{array}{l}\text { Nama kategori } \\
\text { barang }\end{array}$ \\
\hline
\end{tabular}

Setelah data sudah terkumpul, tahap berikutnya ialah pengolahan data dengan cara seleksi data atau membersihkan data (data cleaning) pada data transaksi penjualan tersebut. Tahap ini bertujuan untuk menentukan atribut beserta value yang dibutuhkan dan akan diproses pada tahap berikutnya. Seleksi data yang dimaksud adalah sebagai berikut:

a. Menghapus data yang memiliki value VOID dan REFUND pada field "OK" ("VOID" = batal transaksi, "REFUND" = ganti barang).

b. Menghapus transaksi Kategori "OTHER STATIONARY", "OTHER BMS BUKU", "OTHER" sebab berisi kantong plastik dan barang Joint Bussiness yang sudah ditentukan (tetap) lokasinya.

c. Menghapus nilai 003 dan 005 (nomor mesin yang digunakan untuk pameran luar toko) pada field "NoMesin".

d. Memilih dan menghapus atribut/field yang tidak dibutuhkan.

e. Merubah Nama Atribut "No_Transaksi_Header" menjadi "NoTrans" serta mengubah nilainya dimulai dari transaksi "1" misalnya "190901001000001" menjadi "1", "190901001000002" menjadi "2", "190901001000003" menjadi "3" dan seterusnya. Tujuannya supaya mudah untuk mengidentifikasi berapa banyak 
jumlah transaksi dan memudahkan dalam pengolahannya.

f. Menghapus kategori barang yang sama dalam satu transaksi. Gambar 4, transaksi "4" berisi kategori barang yang sama yaitu "NOVEL", maka hanya dihitung satu kali transaksi. Begitu juga pada transaksi "7" ada dua kategori "WRITING INSTRUMENT", juga tetap dihitung satu kali transaksi, dan seterusnya.

\begin{tabular}{|c|c|c|c|}
\hline NoTrans Nama_Kategori & Kode_Kategori & NoTrans Nama_Kategori & Kode_Kategor \\
\hline 1 FANCY \& GIFT & 1 & 1 FANCY \& GIFT & 1 \\
\hline 2 TECHNOLOGY & B & 2 TECHNOLOGY & B \\
\hline 2 OFFICE ESSENTIAL & $\mathrm{F}$ & 2 OFFICE ESSENTIAL & $\mathrm{F}$ \\
\hline 3 BUKU AGAMA ISLAM & $\mathrm{N}$ & 3 BUKU AGAMA ISLAM & $\mathrm{N}$ \\
\hline 4 NOVEL & u & 4 NOVEL & u \\
\hline 4 NOVEL & u & 5 NOVEL & u \\
\hline 5 NOVEL & u & 6 FILE MAP & D \\
\hline 6 FLLE MAP & D & 7 WRITING INSTRUMENT & H \\
\hline 7 WRITING INSTRUMENT & H & 7 PAPER & E \\
\hline 7 WRITING INSTRUMENT & H & 7 BUKU AGAMA ISLAM & $\mathrm{N}$ \\
\hline 7 PAPER & E & 8 WRITING INSTRUMENT & H \\
\hline 7 BUKU AGAMA ISLAM & $\mathrm{N}$ & 8 PAPER & E \\
\hline 8 WRITING INSTRUMENT & H & 8 OFFICE ESSENTIAL & $\mathrm{F}$ \\
\hline 8 PAPER & E & 9 AGAMA \& FILSAFAT & $T$ \\
\hline 8 OFFICE ESSENTIAL & F & 10 WRITING INSTRUMENT & H \\
\hline 9 AGAMA \& FILSAFAT & $T^{\top}$ & 11 FILE MAP & D \\
\hline 10 WRITING INSTRUMENT & H & 12 NOVEL & u \\
\hline 10 WRITING INSTRUMENT & H & 13 AGAMA \& FILSAFAT & T \\
\hline 11 FILE MAP & $\begin{array}{l}D \\
U\end{array}$ & 14 WRITING INSTRUMENT & H \\
\hline $\begin{array}{l}12 \text { NOVEL } \\
13 \text { AGAMA \& FISAFAT }\end{array}$ & $\begin{array}{l}U \\
T\end{array}$ & 15 BUKU ANAK & $p$ \\
\hline $\begin{array}{l}13 \text { AGAMA \& FILSAFAT } \\
14 \text { WRITING INSTRUMENT }\end{array}$ & H & 16 BUKU ANAK & $\mathrm{p}$ \\
\hline $\begin{array}{l}14 \text { WRITING INSTRUMENT } \\
15 \text { BUKU ANAK }\end{array}$ & p & 16 BUKU AGAMA ISLAM & $\mathrm{N}$ \\
\hline $\begin{array}{l}15 \text { BUKU ANAK } \\
15 \text { BUKU ANAK }\end{array}$ & p & 17 BUKU ANAK & $p$ \\
\hline 16 BUKU ANAK & P & 18 TOYS \& SPORT MUSIC & J \\
\hline \multirow[t]{2}{*}{16 BUKU AGAMA ISLAM } & N & 18 FANCY \& GIFT & I \\
\hline & & 19 NOVEL & u \\
\hline
\end{tabular}

Gambar 4. Menghapus kategori yang sama dalam satu transaksi

Data yang dihasilkan setelah melalui proses seleksi data adalah sebanyak 57.449 transaksi dengan 133.571 record.

Setelah tahap seleksi data, tahap selanjutnya ialah tahap transformasi data dengan cara menyimpan data siap mining tersebut dalam bentuk tabular dengan format .xlsx (Microsoft Office Excel 2007). Apabila item ada dalam transaksi, maka akan diisi nilainya (Nama_Kategori) pada kolom kode kategori. Pada Gambar 5, misalnya pada transaksi 1 (baris ke-2) diisi dengan nilai
"FANCY \& GIFT" pada kolom "Kategori I" (sesuai dengan kode kategori).

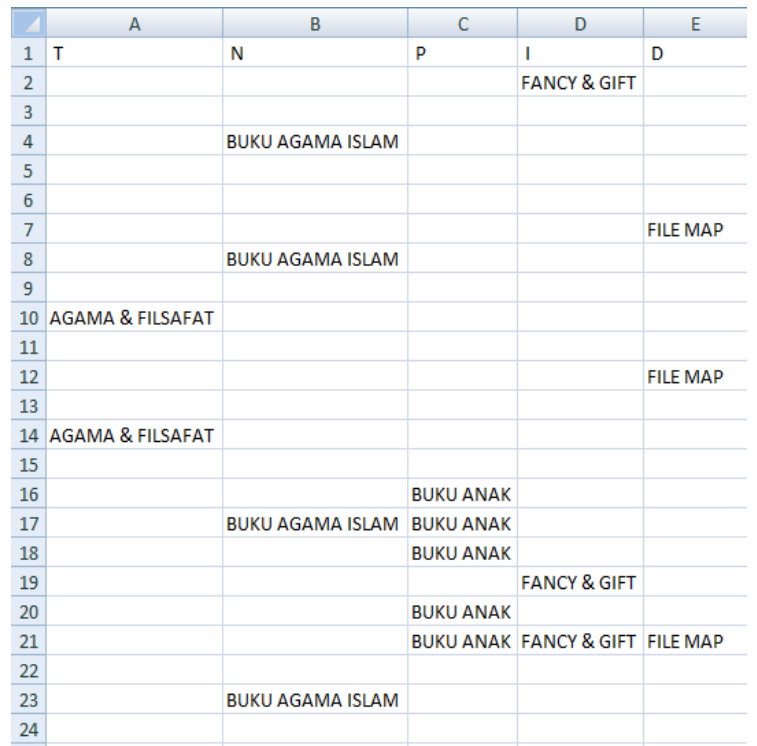

Gambar 5. Data Tabular

Tahap berikutnya adalah implementasi. Pada tahap ini dilakukan pengujian data menggunakan teknik data mining asosiasi algoritma FP-Growth, baik secara manual maupun menggunakan tools Rstudio. Hasil dari proses ini adalah aturan atau rule transaksi konsumen.

Tahap akhir dari penelitian ini adalah melakukan analisa rule hasil implementasi algoritma FP-Growth. Analisa yang maksud ialah mengidentifikasi pola atau pengetahuan baru berupa hubungan antar kategori barang sebagai dasar untuk mengatur tata letak barang dagangan.

\section{HASIL DAN PEMBAHASAN}

4.1. Perhitungan Manual 100 Transaksi Pertama Menggunakan AlgoritmaFPGROWTH

a. Menghitung dan mengurutkan frekuensi (support count), menentukan minimum support, dan menentukan nilai priority serta mengurutkan item transaksi berdasarkan priority. 
Tabel 2. Mengurutkan kategori berdasarkan support count dan memberi nilai priority

\begin{tabular}{|c|c|c|c|}
\hline $\begin{array}{c}\text { Kode } \\
\text { Kategori }\end{array}$ & Nama Kategori & Support Count & Priority \\
\hline G & SCHOOL STATIONERY & 18 & 1 \\
\hline N & BUKU AGAMA ISLAM & 17 & 2 \\
\hline H & WRITING INSTRUMENT & 17 & 3 \\
\hline I & FANCY \& GIFT & 16 & 4 \\
\hline P & BUKU ANAK & 14 & 5 \\
\hline F & OFFICE ESSENTIAL & 10 & 6 \\
\hline U & NOVEL & 8 & 7 \\
\hline R & PEND.DASAR\&MENENGAH & 8 & 8 \\
\hline D & FILE MAP & 7 & 9 \\
\hline O & PRODUK ISLAMI & 7 & 10 \\
\hline B & TECHNOLOGY & 5 & 11 \\
\hline T & AGAMA \& FILSAFAT & 4 & 12 \\
\hline S & HOBBY \& KESEHATAN & 4 & 13 \\
\hline V & MANAJEMEN \& PERTI & 4 & 14 \\
\hline E & TOYS \& SPORT MUSIC & 4 & 15 \\
\hline J & & 4 & 16 \\
\hline
\end{tabular}

b. Pembentukan FP-Tree

Pada tahap ini dilakukan pembentukan FP-Tree. FP-Tree dibentuk berdasarkan kategori barang yang sudah diurutkan berdasarkan priority untuk setiap transaksi. Maka, secara visualisasi pembentukan tree untuk setiap transaksi tersebut adalah sebagai berikut:

Pada transaksi 1 berisi 1 item kategori dengan kode kategori I (Gambar 5). Maka hasil pembentukan Tree seperti pada Gambar 6.

Tabel 3. Jumlah support count mulai transaksi 1

\begin{tabular}{|c|c|c|}
\hline Priority & \multicolumn{1}{|c|}{ Nama Kategori } & Jumlah \\
\hline G & SCHOOL STATIONERY & \\
\hline N & BUKU AGAMA ISLAM & \\
\hline
\end{tabular}

\begin{tabular}{|c|l|c|}
$\mathrm{H}$ & WRITING INSTRUMENT & \\
\hline $\mathrm{I}$ & FANCY \& GIFT & 1 \\
\hline $\mathrm{P}$ & BUKU ANAK & \\
\hline $\mathrm{F}$ & OFFICE ESSENTIAL & \\
\hline $\mathrm{U}$ & NOVEL & \\
\hline $\mathrm{R}$ & PEND.DASAR\&MENENGAH & \\
\hline $\mathrm{D}$ & FILE MAP & \\
\hline $\mathrm{O}$ & PRODUK ISLAMI & \\
\hline $\mathrm{B}$ & TECHNOLOGY & \\
\hline $\mathrm{T}$ & AGAMA \& FILSAFAT & \\
\hline $\mathrm{S}$ & HOBBY \& KESEHATAN & \\
\hline $\mathrm{V}$ & MANAJEMEN \& PERTI & \\
\hline $\mathrm{E}$ & PAPER & \\
\hline $\mathrm{J}$ & TOYS \& SPORT MUSIC & \\
\hline
\end{tabular}




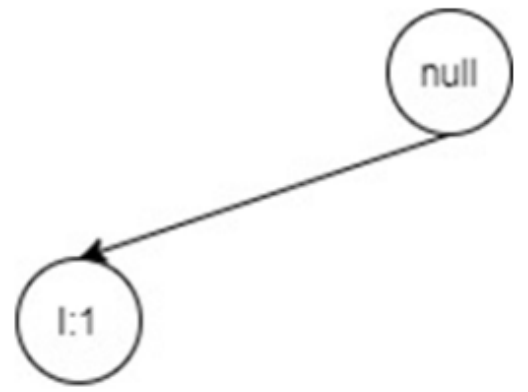

Gambar 6. FP-Tree mulai transaksi 1

Langkah berikutnya adalah mengulangi langkah yang sama seperti langkah di atas sampai pada transaksi 100, sehingga menghasilkan tree seperti Gambar 7 dan jumlah support count (Tabel 4) harus sesuai dengan Tabel 2.

Tabel 4. Jumlah support count sampai transaksi 100

\begin{tabular}{|c|c|c|}
\hline $\begin{array}{c}\text { Priorit } \\
y\end{array}$ & Nama Kategori & $\begin{array}{l}\text { Support } \\
\text { Count }\end{array}$ \\
\hline $\bar{G}$ & SCHOOL STATIONERY & 18 \\
\hline $\mathrm{N}$ & BUKU AGAMA ISLAM & 17 \\
\hline $\mathrm{H}$ & WRITING INSTRUMENT & 17 \\
\hline $\mathrm{I}$ & FANCY \& GIFT & 16 \\
\hline $\mathrm{P}$ & BUKU ANAK & 14 \\
\hline $\mathrm{F}$ & OFFICE ESSENTIAL & 10 \\
\hline $\mathrm{U}$ & NOVEL & 8 \\
\hline $\mathrm{R}$ & $\begin{array}{l}\text { PEND.DASAR\&MENENG } \\
\text { AH }\end{array}$ & 8 \\
\hline $\mathrm{D}$ & FILE MAP & 7 \\
\hline $\mathrm{O}$ & PRODUK ISLAMI & 7 \\
\hline $\bar{B}$ & TECHNOLOGY & 5 \\
\hline $\mathrm{T}$ & AGAMA \& FILSAFAT & 4 \\
\hline $\mathrm{S}$ & HOBBY \& KESEHATAN & 4 \\
\hline $\mathrm{V}$ & MANAJEMEN \& PERTI & 4 \\
\hline $\mathrm{E}$ & PAPER & 4 \\
\hline $\mathrm{J}$ & TOYS \& SPORT MUSIC & 4 \\
\hline
\end{tabular}

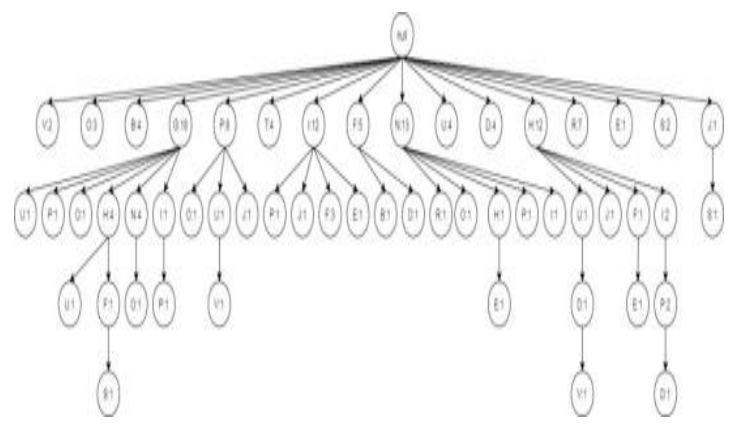

Gambar 7. Tree dan jumlah support count sampai transaksi 100

\section{c. Pembangkitan Conditional Pattern Base}

Pembangkitan Conditional Pattern Base adalah tahap menghitung jumlah transaksi yang mengandung prefix path (lintasan prefix) dan suffix pattern (pola akhiran) dari FP-Tree yang sudah dibentuk pada tahap sebelumnya dimulai dari item yang memiliki support count terkecil. Pada Gambar 8 kategori J melalui lintasan $\mathrm{P}$, I, dan $\mathrm{H}$ dengan nilai support count masing-masing 1 . Sehingga Conditional Pattern Base untuk kategori $\mathrm{J}$ adalah $\{\mathrm{P}: 1\},\{\mathrm{I}: 1\}$, $\{\mathrm{H}: 1\}$ dapat ditulis seperti pada Tabel 5.

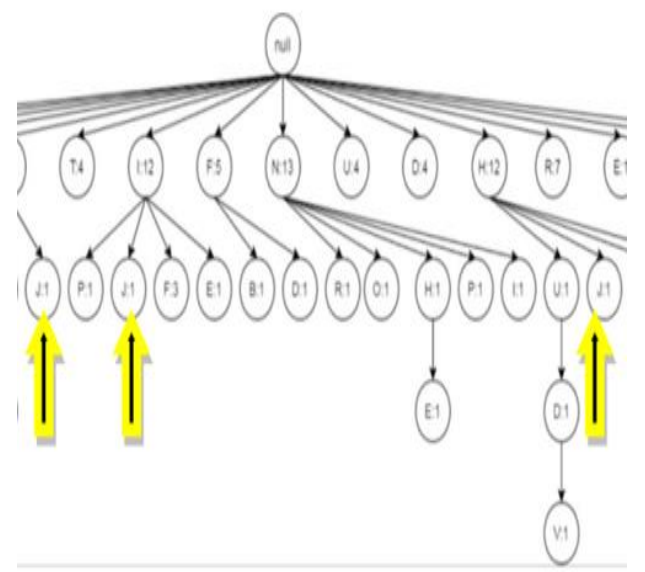

Gambar 8. Lintasan kategori J berdasarkan FP-Tree 
Tabel 5. Hasil tahap Pembangkitan Conditional Pattern Base

\begin{tabular}{|l|l|}
\hline Item & $\begin{array}{l}\text { Pembangkitan Conditional } \\
\text { Pattern Base }\end{array}$ \\
\hline J & $\{\mathrm{P}: 1\},\{\mathrm{I}: 1\},\{\mathrm{H}: 1\}$ \\
\hline E & $\{\mathrm{I}: 1\},\{\mathrm{N}, \mathrm{H}: 1\},\{\mathrm{H}, \mathrm{F}: 1\}$ \\
\hline V & $\{\mathrm{P}, \mathrm{U}: 1\},\{\mathrm{H}, \mathrm{U}, \mathrm{D}: 1\}$ \\
\hline S & $\{\mathrm{G}, \mathrm{H}, \mathrm{F}: 1\},\{\mathrm{J}: 1\}$ \\
\hline T & - \\
\hline B & $\{\mathrm{F}: 1\}$ \\
\hline O & $\begin{array}{l}\{\mathrm{G}, \mathrm{N}: 1\},\{\mathrm{P}: 1\},\{\mathrm{G}: 1\}, \\
\{\mathrm{N}: 1\}\end{array}$ \\
\hline D & $\{\mathrm{F}: 1\},\{\mathrm{H}, \mathrm{U}: 1\},\{\mathrm{H}, \mathrm{I}, \mathrm{P}: 1\}$ \\
\hline R & $\{\mathrm{N}: 1\}$ \\
\hline U & $\begin{array}{l}\{\mathrm{G}: 1\},\{\mathrm{G}, \mathrm{H}: 1\},\{\mathrm{P}: 1\}, \\
\{\mathrm{H}: 1\}\end{array}$ \\
\hline F & $\{\mathrm{G}, \mathrm{H}: 1\},\{\mathrm{I}: 3\},\{\mathrm{H}: 1\}$ \\
\hline P & $\begin{array}{l}\{\mathrm{G}: 1\},\{\mathrm{G}, \mathrm{I}: 1\},\{\mathrm{I}: 1\}, \\
\{\mathrm{N}: 1\},\{\mathrm{H}, \mathrm{I}: 2\}\end{array}$ \\
\hline I & $\{\mathrm{G}: 1\},\{\mathrm{N}: 1\},\{\mathrm{H}: 2\}$ \\
\hline H & $\{\mathrm{G}: 4\},\{\mathrm{N}: 1\}$ \\
\hline N & $\{\mathrm{G}: 4\}$ \\
\hline G & - \\
\hline & \\
\hline
\end{tabular}

Setelah menghitung Conditional Pattern Base sampai pada kategori terakhir (G), maka tahap berikutnya yaitu Pembangkitan Conditional FPTree.

d. Pembangkitan Conditional FP-Tree

Pada tahap ini, support count untuk setiap item (kategori barang) pada setiap Conditional Pattern Base dijumlahkan. Kemudian, untuk setiap kategori yang memiliki jumlah support count lebih besar atau sama dengan minimum support count (4) akan dibangkitkan kembali dengan Conditional FP-Tree. Pada Tabel 5, untuk kategori J masingmasing hanya memiliki support count 1 atau lebih kecil dari minimum support count maka tidak akan dibangkitkan. Untuk kategori P, apabila dijumlahkan untuk masing-masing lintasan maka akan menghasilkan $\mathrm{G}=2, \mathrm{I}=4, \mathrm{~N}=1$, dan $\mathrm{H}=2$. Dari hasil tersebut, maka yang memenuhi syarat hanya kategori I. Sehingga kategori I akan dibangkitkan pada tahap ini. Untuk kategori-kategori lainnya diproses dengan cara yang sama, maka menghasilkan Conditional FPTree seperti pada Tabel 6.

Tabel 6. Hasil tahap Pembangkitan Conditional FP-Tree

\begin{tabular}{|l|l|}
\hline Item & $\begin{array}{l}\text { Pembangkitan } \\
\text { Conditional FP-Tree }\end{array}$ \\
\hline J & - \\
\hline E & - \\
\hline V & - \\
\hline S & - \\
\hline T & - \\
\hline B & - \\
\hline O & - \\
\hline D & - \\
\hline R & - \\
\hline U & - \\
\hline F & - \\
\hline P & $\{$ I:4 $\}$ \\
\hline I & - \\
\hline H & $\{$ G:4 $\}$ \\
\hline N & $\{$ G:4 $\}$ \\
\hline G & - \\
\hline
\end{tabular}

e. Pencarian Frequent Itemset

Pada tahap ini dilakukan pembentukan Frequent Itemset berdasarkan kombinasi item yang dibentuk oleh setiap Conditional FPTree. Maka, hasil dari tahap ini dapat dilihat pada Tabel 7. 
Tabel 7. Hasil tahap Pencarian Frequent Itemset

\begin{tabular}{|l|l|}
\hline Item & Pencarian Frequent Itemset \\
\hline J & - \\
\hline E & - \\
\hline V & - \\
\hline S & - \\
\hline T & - \\
\hline B & - \\
\hline O & - \\
\hline D & - \\
\hline R & - \\
\hline U & - \\
\hline F & - \\
\hline P & $\{$ P,I $\}$ \\
\hline I & - \\
\hline H & $\{$ H,G $\}$ \\
\hline N & $\{$ N,G $\}$ \\
\hline G & - \\
\hline
\end{tabular}

f. Hasil Perhitungan Manual Berupa Rule

Hasil perhitungan manual berupa rule sebagai berikut:

Tabel 8. Rule hasil uji 100 transaksi pertama dengan perhitungan manual

\begin{tabular}{|c|c|c|c|c|c|}
\hline Rule & $\begin{array}{c}\text { Sumlah } \\
\text { Count }\end{array}$ & $\begin{array}{c}\text { Perhitungan } \\
\text { Support }\end{array}$ & Support & $\begin{array}{c}\text { Perhitungan } \\
\text { Confidence }\end{array}$ & Confidence \\
\hline $\begin{array}{c}\text { G } \\
\text { H }\end{array}$ & 4 & $4 / 100$ & 0.04 & $4 / 18$ & 0.222222 \\
\hline $\begin{array}{c}\text { G } \\
\Rightarrow \\
\text { N }\end{array}$ & 4 & $4 / 100$ & 0.04 & $4 / 18$ & 0.222222 \\
\hline $\begin{array}{c}\text { H } \\
\Rightarrow \\
\text { G }\end{array}$ & 4 & $4 / 100$ & 0.04 & $4 / 17$ & 0.235294 \\
\hline $\begin{array}{c}\text { N } \\
\Rightarrow \\
\text { G }\end{array}$ & 4 & $4 / 100$ & 0.04 & $4 / 17$ & 0.235294 \\
\hline $\begin{array}{c}\text { I }=> \\
\text { P }\end{array}$ & 4 & $4 / 100$ & 0.04 & $4 / 16$ & 0.250000 \\
\hline $\begin{array}{c}\text { P } \\
\Rightarrow>\end{array}$ & 4 & $4 / 100$ & 0.04 & $4 / 14$ & 0.285714 \\
\hline
\end{tabular}

4.2. Perhitungan 100 Transaksi Pertama Menggunakan Algoritma FP-GROWTH di Rstudio

a. Install dan load packages

Paket yang perlu di-install dan load antara lain: readxl, arules, Matrix, $r C B A$, dan rJava. Serta "arulesViz" apabila rule akan divisualisasikan.

b. Import Dataset

Import dataset dengan cara klik Import Dataset -> From Excel -> Browse -> Pilih file yang sudah diupload -> Open -> Import.

c. Ubah tipe data

Tipe dataset diatas merupakan data mentah dan belum siap diolah sehingga harus diubah menjadi tipe data transaksional dengan $R$ script sebagai berikut:

train <- sapply(NamaDataset, as.factor)

$d f<-$ data.frame(train, check.names $=$ FALSE)

trans <- as $(d f$,"transactions")

d. Proses pengujian Asosiasi Data Mining Algoritma FP-Growth

Script yang digunakan untuk pengujian data menggunakan algoritma FP-Growth dengan parameter minimal support 0.04 dan confidence 0.2 adalah sebagai berikut:

rules $=r C B A::$ fpgrowth (trans, support $=0.04$, confidence $=0.2$, maxLength $=5$, consequent $=$ "[KodeKategori]", parallel $=$ FALSE) 


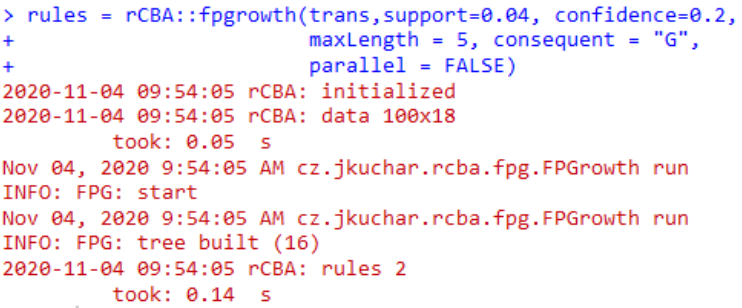

Gambar 9. Uji algoritma FP-Growth

$$
\text { consequent }=" G "
$$

Untuk menampilkan rule yang dihasilkan dapat menggunakan script berikut:

\section{$\operatorname{View}($ inspect(rules))}

Apabila script di atas dijalankan maka akan menghasilkan output seperti pada Gambar 10.

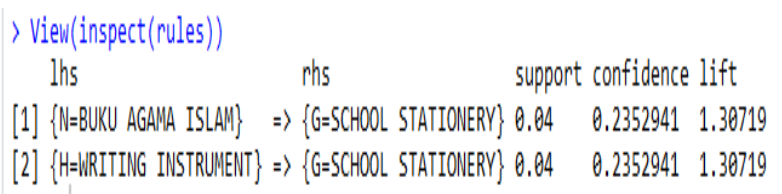

Gambar 10. Rule hasil uji algoritma FPGrowth consequent=" $G$ "

Dengan mengulangi langkah yang sama dan dengan consequent semua kode kategori, maka menghasilkan rule berikut (Gambar 11).

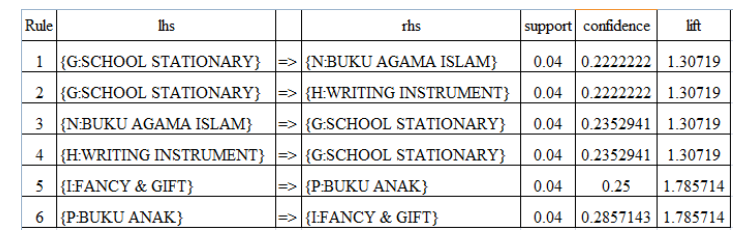

Gambar 11. Rule hasil uji 100 transaksi di

\section{Rstudio}

Berdasarkan hasil perhitungan 100 transaksi secara manual pada Tabel 8 dan dengan Rstudio pada Gambar 11 menggunakan algoritma FP-Growth dengan parameter minimum support $=0.04$ dan confidence $=0.2(20 \%)$ telah dihasilkan 6 rule asosiasi yang sama

\subsection{Implementasi Algoritma FP-GROWTH} Semua Dataset Menggunakan Rstudio

Pada tahap ini dilakukan perhitungan untuk semua dataset periode 1 tahun (1 September 2019 sampai 31 Agustus 2020) yaitu sebanyak 57.449 transaksi dengan 133.571 record di Rstudio dengan menggunakan langkah seperti pada nomor 4.2. Dari perhitungan tersebut menghasilkan rule sebagai berikut:

\begin{tabular}{|c|c|c|c|c|c|c|}
\hline Rule & ths & & ths & support & confidence & lift \\
\hline 1 & \{\} & $\Rightarrow$ & $\{\mathrm{H}=$ WRITNG INST & 0.20477293 & 0.2047729 & 1 \\
\hline 2 & $\{H=W R I T N G$ NSTR & $\Rightarrow$ & $\{\mathrm{F}=0$ FFICE ESSE & 0.0450904 & 217358 & 1.2933 \\
\hline 3 & \{\} & $\Rightarrow$ & $\{1=F A N C Y \&$ & 0.2191161 & 2191161 & \\
\hline 4 & $\{\mathrm{~F}=0$ FFICE ESS & $\Rightarrow$ & $\{\mathrm{H}=\mathbb{W}$ RITNG $\mathrm{NS}$ & 0.04450904 & 2648369 & 1.29 \\
\hline 5 & $\{\mathrm{H}=$ WRITNG INSTRUMENT $\}$ & $\Rightarrow$ & $\{\mathrm{G}=$ SCHOOL STATIONERY $\}$ & 0.05672858 & 0.2770316 & 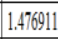 \\
\hline 6 & $\{\mathrm{G}=$ SCHOOL STATIONERY $\}$ & $\Rightarrow$ & $\{\mathrm{H}=\mathbb{W R T I N G}$ NSTRUMENT $\}$ & 0.05672858 & 0.3024313 & 1.476 \\
\hline
\end{tabular}

Gambar 12. Rule hasil uji semua transaksi di

$$
\text { Rstudio }
$$

1. Jika membeli barang dengan kategori $\mathrm{H}$ (WRITING INSTRUMENT), maka akan membeli barang dengan kategori $F$ (OFFICE ESSENTIAL) dengan nilai confidence $22 \%$.

2. Jika membeli barang dengan kategori $\mathrm{F}$ (OFFICE ESSENTIAL), maka akan membeli barang dengan kategori $\mathrm{H}$ (WRITING INSTRUMENT) dengan nilai confidence $26 \%$.

3. Jika membeli barang dengan kategori $\mathrm{H}$ (WRITING INSTRUMENT), maka akan membeli barang dengan kategori $G$ (SCHOOL STATIONERY) dengan nilai confidence $28 \%$.

4. Jika membeli barang dengan kategori $\mathrm{G}$ (SCHOOL STATIONERY), maka akan membeli barang dengan kategori $\mathrm{H}$ (WRITING INSTRUMENT) dengan nilai confidence $30 \%$. 


\section{SIMPULAN DAN SARAN}

\subsection{Simpulan}

Berdasarkan hasil penelitian data mining asosiasi algoritma FP-Growth pada data transaksi penjualan Toko Gunung Agung Cabang Semarang, dapat diambil kesimpulan bahwa perhitungan algoritma FP-Growth dengan parameter minimum support 0.04 dan confidence 0.2 secara manual dan menggunakan tools Rstudio untuk 100 transaksi pertama telah menghasilkan rule asosiasi yang sama. Dan untuk mengatur tata letak barang berdasarkan perhitungan semua data periode 1 tahun (1 September 2019 sampai 31 Agustus 2020), barang dengan kode kategori $\mathrm{H}$ (WRITING INSTRUMENT) harus diletakkan berdekatan dengan barang dengan kode kategori G (SCHOOL STATIONERY) dan barang dengan kategori $F$ (OFFICE ESSENTIAL).

\subsection{Saran}

Saran untuk penelitian selanjutnya yaitu bisa menggunakan variabel lain, misalnya variabel item barang. Menggunakan metode asosiasi dalam strategi bisnis, selain bisa mengelompokkan item-item barang dalam satu tempat, juga akan berguna untuk mengadakan program promo seperti diskon, beli 2 dapat 3, potongan harga saat event tertentu, dan lain sebagainya.

\section{DAFTAR PUSTAKA}

Marsono, M. (2019). Penerapan Data Mining Pengaturan Pola Tata Letak Barang Pada Berkah Swalayan Untuk Strategi Penjualan Menggunakan Algoritma Apriori. InfoTekJar (Jurnal Nasional Informatika Dan Teknologi Jaringan), $3(2)$, 170-175. https://doi.org/10.30743/infotekjar.v3i2 .908
Maulidiya, H., \& Jananto, A. (2020). Asosiasi Data Mining Menggunakan Algoritma Apriori Dan Fp-GROWTH SEBAGAI DASAR PERTIMBANGAN PENENTUAN PAKET SEMBAKO. Proceeding SENDIU 2020, 6, 36-42.

Prahartiwi, L. I. (2017). Pencarian Frequent Itemset pada Analisis Keranjang Belanja Menggunakan Algoritma FPGrowth. Information System For Educators And Professionals, 2(1), 110.

Prasetyo, Eko (2012). DATA MINING Konsep dan Aplikasi Menggunakan MATLAB.Yogyakarta: Andi Offset.

Salam, A., Zeniarja, J., Wicaksono, W., \& Kharisma, L. (2019). Pencarian Pola Asosiasi Untuk Penataan Barang Dengan Menggunakan Perbandingan Algoritma Apriori Dan Fp-Growth (Study Kasus Distro Epo Store Pemalang). Dinamik, 23(2), 57-65. https://doi.org/10.35315/dinamik.v23i2. 7178

Santosa, Budi (2007). Data Mining: Teknik Pemanfaatan Data untuk Keperluan Bisnis. Yogyakarta: Graha Ilmu

Witten, Ian H., Erbe Frank, Mark A. Hall \& Christopher J. Pal. (2017) DATA MINING: Practical Machine Learning Tools and Techniques 4th Edition. San Fransisco: Morgan Kaufmann, United States.

Yanto, R., \& Kesuma, H. Di. (2017). Pemanfaatan Data Mining Untuk Penempatan Buku Di Perpustakaan Menggunakan Metode Association Rule. JATISI (Jurnal Teknik Informatika Dan Sistem Informasi), 4(1), 1-10. https://doi.org/10.35957/jatisi.v4i1.83 